\title{
Early Childhood Education Learning Strategy During The Covid-19 Pandemic
}

\section{Arsyia Fajarrini}

Received: 29032021 / Accepted: 25062021 / Published online: 30062021

(C) 2021 Association of Indonesian Islamic Early Childhood Education Study Program

\begin{abstract}
Abstrak Hingga bulan maret ini pandemi Covid-19 masih melanda Indonesia, pandemi ini memberikan dampak buruk terhadap pendidikan Indonesia, terlebih di jenjang pendidikan Anak Usia Dini. Proses pembelajaran yang awalnya tatap muka berubah menjadi pembelajaran jarak jauh, hal ini menjadi bukti nyata dampak dari Covid-19. Untuk mewujudkan tujuan pembelajaran secara optimal, diperlukan strategi pembelajaran yang berbeda. Oleh sebab itu, tujuan dari penelitian ini adalah untuk mengkaji penerapan strategi pembelajaran PAUD di tengah pandemi covid-19. Jenis penelitian yang digunakan adalah kualitif deskriptif. Subjek dalam penelitian ini adalah guru dan walimurid. Pengumpulan data penelitian dengan menggunakan wawancara dan observasi. Sedangkan untuk menguji keabsahan data dengan triangulasi teknik dan sumber. Penerapan strategi pembelajaran yang dilakukan oleh guru saat pandemi covid-19 dengan pembelajaran daring dan luring. Pembelajaran daring dengan menggunakan sosial media berupa youtube dan whatsApp, sedangkan pembelajaran luring dengan home visit berkelompok. Pembelajaran luring guna untuk menutup kekurangan pembelajaran daring yang memiliki beberapa permasalahan.
\end{abstract}

Kata Kunci: strategi, daring, luring.

\begin{abstract}
As of March, the Covid-19 pandemic is still hitting Indonesia, this pandemic has a negative impact on Indonesian education, especially in the early childhood education level. The learning process, which initially turned into distance learning, is proof of the real impact of Covid-19. To achieve optimal learning objectives, different learning strategies are needed. Therefore, the aim of this study is to examine the implementation of early childhood learning strategies in the midst of the Covid-19 pandemic. The type of research used is descriptive qualitative. The subjects in this study were teachers and pupils. The data technique used interviews and observations. Meanwhile, to test the validity of the data by triangulation of techniques and sources. The application of learning strategies carried out by teachers during the Covid-19 pandemic with bold and offline learning. Bold learning using social media in the form of YouTube and WhatsApp, while offline learning involves group home visits. Offline learning to cover learning deficiencies that has several problems.
\end{abstract}

Keywords: Strategic, online, ofline

\section{Pendahuluan}

Saat ini dunia sedang di kejutkan dengan mewabahnya suatu penyakit yang disebabkan oleh sebuah virus yang bernama Corona yang memiliki nama lain Covid-19 (Corona Virus dissease-19). Virus ini disinyalir mulai mewabah pada bulan Desember 2019 di Kota Wuhan Provinsi Hubai Tiongkok. Corona Virus hampir menyebar ke seluruh dunia dengan sangat cepat, sehingga otoritas kesehatan dunia WHO menetapkan wabah ini sebagai pandemi global. Wabah virus corona masih terus melanda sejumlah negara di dunia, salah satunya Indonesia. 
Pada tanggal 2 Maret 2019 presiden Republik Indonesia Ir. Joko Widodo mengumumkan dua kasus pasien positif Covid-19 (Kompas.com, diakses pada 29 Januari 2021, pukul 19.00). Pada awalnya warga Indonesia yang terinfeksi virus corona bertemu dengan WNA asal Jepang, selang 2 hari WNI tersebut terkena sakit batuk, hingga akhirnya virus corona sampai ke pasien kedua. Sampai saat ini angka penderita corona di Indonesia setiap harinya semakin meningkat. Hingga jumat, 29 Januari 2021 ada tambahan 13.802 kasus baru yang terinfeksi corona di Indonesia, sehingga total keseluruhan menjadi 1.051.795 kasus positif corona (covid19.go.id, diakses pada 29 Januari 2021, pukul 19.30) Masa pandemi sangat berdampak pada semua sektor. Perekonomian menjadi lemah, banyak pabrik-pabrik yang tutup, banyak pekerja yang dirumahkan, sehingga daya beli masyarakat rendah. Di sektor pariwisata juga melemah, karena adanya anjuran dari pemerintah untuk tetap dirumah, menjaga jarak. Hal ini memaksa tutupnya hotel dan tempat-tempat wisata yang mengakibatkan banyak karyawan yang dirumahkan.

Tidak hanya di sektor ekonomi dan pariwisata, corona juga sangat berdampak pada sektor pendidikan. Mengantisipasi jumlah penularan yang semakin naik, pemerintah daerah dan pusat mengambil kebijakan secara tegas bahwa sekolah diliburkan diganti dengan pembelajaran jarak jauh (online) disemua jenjang pendidikan. Hal ini sudah lebih dulu dilakukan oleh negaranegara lain yang sudah terdampak virus corona terlebih dahulu. Adanya pembatasan dalam pelaksanaan pembelajaran, menuntut pemerintah, kepala sekolah serta guru untuk memberikan alternatif pembelajaran bagi peserta didik. Dengan memberikan alternatif dalam pembelajaran tersebut, diharapkan dapat meminimalisir masyarakat yang positif Covid-19. Sejak adanya corona di Indonesia, pemerintah pusat mengambil kebijakan tegas bahwa aktivitas yang melibatkan banyak orang mulai dibatasi, seperti sekolah, beribadah, bekerja dan lain sebagainya. Pemerintah menghimbau untuk belajar, bekerja dan beribadah sementara waktu dilakukan dirumah saja. Hal ini dilakukan bertujuan untuk menekan angka positif corona di Indonesia. Pembatasan kegiatan masyarakat sampai saat ini masih di lakukan, terbaru adanya kebijakan pemerintah terkait PSBB Jawa Bali mulai dari tanggal 11-25 Januari 2021 (Kominfo, 2021). Menteri Airlangga Hartanto menyampaikan PSBB Jawa-Bali dilakukan, karena mencermati perkembangan pandemi covid-19 dan adanya varian baru virus covid-19 yang lebih cepat menular. Oleh karena itu pemerintah mengeluarkan kebijakan terbaru dengan adanya pemberlakuan pembatasan kegiatan masyarakat.

Berlakunya pembatasan kegiatan masyarakat, tentu menimbulkan banyak problematika di sektor pendidikan, terutama di jenjang pendidikan anak usia dini. Pendidikan anak usia dini (PAUD) merupakan upaya untuk memberikan stimulasi, membimbing, mengasuh, memberikan pembelajaran pada seluruh aspek pertumbuhan dan perkembangan anak, agar anak memiliki kesiapan dalam memasuki jenjang pendidikan lebih lanjut. Adanya pembelajaran daring (online) tidak hanya berdampak pada peserta didik saja, tapi juga berdampak pada pendidik, pendidik juga harus beradaptasi dengan sistem pembelajaran yang baru. Dalam menghadapi pembelajaran online guru masih membutuhkan pendampingan, pelatihan dan pengarahan teknis untuk melaksanakan materi pembelajaran yang adaptif sesuai dengan kondisi pandemi saat ini (Indahri, 2020,P.16) Sebelumnya pembelajaran secara langsung dapat mencakup semua aspek perkembangan dan afektif. Namun kini berubah menjadi pembelajaran daring atau pembelajaran jarak jauh. Hal ini tentu saja sangat berpengaruh pada tahap perkembangan anak. Pembelajaran secara langsung dapat memberikan motivasi pada anak, anak lebih semangat belajar karena dalam pembelajaran anak dilibatkan secara langsung. Sebelum berlakunya pembelajaran jarak jauh (PJJ) lembaga PAUD biasanya sangat intens dalam memberikan stimulasi perkembangan peserta didik, melalui kegiatan-kegiatan yang dikemas secara menarik, sehingga anak dapat bermain sambil belajar. Zaini menyatakan bahwa pembelajaran yang sesuai untuk anak usia dini adalah dengan bermain (Zaini, 2015). Bermain menjadi aktivitas yang menyenangkan bagi anak-anak, dalam pembelajaran jarak jauh guru juga harus memberikan strategi pembelajaran yang menarik, tapi mencakup semua aspek perkembangan anak. Pada pendidikan anak usia dini, lingkungan bermain menjadi hal yang terpenting yang dibutuhkan anak untuk merangsang semua aspek perkembangan anak (Pg-paud, Keguruan, and Nusantara 2020). Karena pendidikan anak usia dini merupakan pendidikan yang memiliki peranan sangat penting untuk 
mengembangkan potensi awal anak dan untuk mempersiapkan anak mengikuti jenjang pendidikan yang selanjutnya (sekolah dasar). Hal ini bila diabaikan maka akan sangat berdampak pada potensi dan perkembangan anak dalam mengikuti jenjang pendidikan selanjutnya. Pembelajaran jarak jauh merupakan suatu bentuk transformasi dari pembelajaran tatap muka ke bentuk pembelajaran yang dikemas dalam bentuk digital yang tentunya memiliki tantangan tidak hanya pada pendidik, tapi juga pada peserta didik dan orangtua. Oleh sebab itu, karena banyak tantangan yang harus dihadapi, lembaga Pendidikan Anak Usia Dini harus dapat menemukan solusi untuk mengatasi permasalahan ini. Penerapan strategi pembelajaran yang pas bisa menjadi salah satu solusi untuk menyelesaikan permasalahan tersebut. Penelitian ini meneliti tentang sejauh mana strategi pembelajaran yang diterapkan oleh pendidik PAUD di tengah pandemi Covid-19. Tujuan penelitian ini untuk mengetahui strategi pembelajaran PAUD di tengah pandemi Covid-19 di RA Ar Rasyid, Kartasura.

\section{Metode}

Penelitian ini menggunakan metode kualitatif deskriptif. Metode kualitatif merupakan suatu strategi inquiry yang menekankan pada pencarian makna, konsep, karakterisitik, deskripsi tentang suatu fenomena, yang bersifat alami dan menyeluruh, serta disajikan secara naratif. (Muri, 2016: 329). Subjek penelitian dalam penelitian ini adalah 4 guru dan 3 walimurid RA Ar Rasyid di Kartasura. Pengumpulan data dalam penelitian ini dengan menggunakan wawancara, dokumentasi dan observasi. Wawancara dilakukan melalui whatsapp dan secara langsung. Data kemudian dianalisis menggunakan model interaktif dari Miles dan Huberman yang terdiri atas empat tahapan yaitu pengumpulan data, mereduksi data, display data, dan penarikan kesimpulan. Penelitian ini dilakukan selama satu bulan, dari bulan 10 Februari-18 Maret 2021. Teknik untuk menguji keabsahan data yaitu dengan teknik triangulasi. Pada penelitian ini, dalam teknik keabsahan datanya menggunakan triangulasi sumber dan triangulasi teknik.

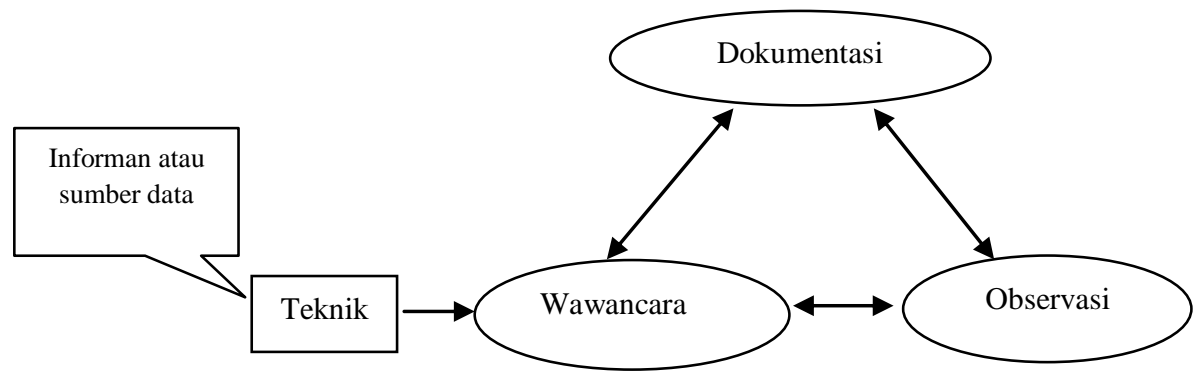

Gambar 1. Alur dalam triangulasi teknik

\section{Hasil Penelitian}

Strategi merupakan suatu teknik yang digunakan untuk mencapai suatu tujuan. Strategi pembelajaran adalah teknik penyusunan model pembelajaran dan metode pembelajaran yang bervariasi yang dapat digunakan untuk mencapai tujuan pembelajaran. Strategi pembelajaran adalah penyusunan pola kemungkinan variasi dalam arti dan macam urutan dalam mengajar (Suriansyah \& Aslamiah, 2011, p.1). Tentunya setiap lembaga Pendidikan Anak Usia Dini memiliki strategi pembelajaran yang berbeda-beda, karena dalam penerapan strategi pembelajaran disesuaikan dengan karakteristik masing-masing lembaga. Terlebih dalam situasi pandemi Covid-19 ini, pastinya strategi pembelajaran berbeda dengan stategi pembelajaran sebelum pandemi. Sebelumnya pembelajaran berpusat pada guru dan siswa, tapi dengan adanya corona beralih pada orangtua dan murid (Hewi and Asnawati 2020). Oleh karena itu, dapat disimpulkan strategi pembelajaran di tengah pandemi Covid merupakan kegiatan merencanakan pembelajaran yang didalamnya mencakup teknik, pola, langkah, serta penggunaan metode yang dilakukan oleh guru, dalam pembelajaran di tengah pandemi agar tujuan serta aspek pembelajaran dapat dicapai secara efektif dan efisien. Banyak cara yang dapat dilakukan 
pendidik dalam menyampaikan pembelajaran ditengah pandemi pada anak usia dini. Tetapi pendidik harus menyesuaikan dengan kondisi peserta didik di masing-masing lembaga dan cara belajar AUD. Cara belajar anak usia dini adalah bermain sambil belajar. Hal ini juga diungkapkan oleh Piaget dalam (Syamsiyati, dkk, 2019: 131) bahwa anak lebih banyak belajar dengan bermain, melakukan percobaan dengan menggunakan benda nyata dan melalui pengalaman yang konkret. Maka dari itu, pembelajaran jarak jauh ini memberikan tantangan tersendiri bagi pendidik anak usia dini. Karena pendidik harus menyiapkan formula strategi pembelajaran yang berbeda, agar materi dapat tersampaikan dengan efisien.

Adanya pandemi corona, pemerintah mengintruksikan untuk melakukan pembelajaran secara daring atau belajar dari rumah. Heny Djoehaeni (2020) dalam Webinar yang berjudul Strategi Pembelajaran PAUD di Masa Pandemi Covid-19, Sekolah Pascasarjana Universitas Pendidikan Indonesia, salah satunya adalah mengedepankan prinsip kebijakan pendidikan di masa pandemi covid-19, yang menjadi prioritas utama adalah kesehatan dan keslamatan seluruh pihak dalam menetapkan kebijakan pembelajaran di jenjang pendidikan. Dalam hal ini pemerintah berupaya mengutamakan kesehatan dan keslamatan semua pihak di jenjang pendidikan dalam menanggulangi dan mencegah penularan Covid-19. Guru mengajar dari rumah, peserta didik belajar dari rumah secara daring atau luring. Selama pandemi, institusi pendidikan sangat bergantung pada gadget dan jaringan internet. Oleh karena itu, diperlukan strategi pembelajaran yang didalamnya mencakup metode, pola serta langkah agar proses belajar mengajar tetap dapat berjalan dengan efektif dan efisien dalam rangka mencerdaskan anak bangsa. Sehingga anak tetap nyaman, semangat dan tidak mudah bosan dalam mengikuti pembelajaran jarak jauh (PJJ).

\section{Belajar dari Rumah}

Sejak masuknya virus corona di Indonesia, pemerintah Indonesia menghimbau masyarakat untuk social distancing (jaga jarak) dengan menerapkan sistem pembelajaran daring/online (jarak jauh), dengan adanya himbauan tersebut diharapkan dapat memutus rantai penyebaran covid-19 di Indonesia. Berdasarkan Peraturan Menteri Pendidikan dan Kebudayaan Republik Indonesia Nomor 119 Tahun 2014, tentang penyelengaraan pendidikan jarak jauh jenjang pendidikan dasar dan menengah, menyebutkan pembelajaran jarak jauh (PJJ) merupakan pendidikan yang peserta didik terpisah dari pendidik dan pembelajarannya menggunakan berbagai sumber belajar melalui penerapan prinsip-prinsip teknologi pendidikan (Kemendikbud 2014). Pandemi Covid merubah tatanan kehidupan masyarakat Indonesia. Salah satu perubahan yang nyata adalah adanya anjuran dari pemerintah yaitu belajar dari rumah (Kemendikbud, 2020) Dengan adanya belajar dari rumah berarti orangtua menjadi pendidik bagi anaknya. Kegiatan pembelajaran di rumah oleh orangtua sebagai pendidik dan anak menjadi peserta didik, tentunya menjadi sesuatu yang tidak biasa dan menantang. Belajar di rumah berarti anak berada di rumah mengikuti pelajaran dengan guru dari tempat yang berbeda (Zamzami 2020). Pelaksanaan pembelajaran yang tidak hanya fokus pada capaian kurikulum sekolah untuk lulus atau naik kelas saja, tetapi orangtua juga diarahkan untuk menciptakan pengalaman pembelajaran yang bermakna bagi anak. Meskipun belajar bersama orangtua, anak harus diberikan pembelajaran yang positif. Adanya kemajuan teknologi digital memudahkan orangtua untuk mendampingi anak dalam pembelajaran jarak jauh meskipun tanpa guru.

Tentunya dalam pandemi ini komunikasi yang baik antara guru dengan orangtua sangat diperlukan, karena guru menjadi penghubung antara guru dengan orangtua dalam menerapkan strategi pembelajaran di tengah pandemi Covid-19. Komunikasi yang dibangun oleh guru dalam bentuk pertemuan menyampaikan pembelajaran pada orang tua setiap dua minggu sekali ke sekolah. Pertemuan antara guru dengan orangtua bertujuan untuk menyampaikan kegiatankegiatan apa saja yang akan dilaksanakan dalam dua minggu, serta memberikan alat dan bahan pendukung pembelajaran. Tentunya dalam pertemuan antara guru dengan orangtua tetap mematuhi protokol kesehatan. Pertemuan antara guru dengan orang tua setiap dua minggu sekali, memberikan dampak yang positif dalam proses pembelajaran. Orang tua dapat mengetahui pencapaiaan perkembangan anaknya dan orang tua dapat bertukar informasi dengan guru mengenai proses belajar anak sehari-hari. Untuk memudahkan orang tua dalam 
mendampingi peserta didik belajar, maka diberikan panduan belajar selama dua minggu yang disesuaikan dengan tema pembelajaran. Dalam panduan belajar tersebut sudah di tuliskan secara rinci, diantaranya tema pembelajaran, sub tema pembelajaran, tugas setiap hari, alat dan bahan yang dibutuhkan, serta materi yang perlu disampaikan pada peserta didik.

\section{Pembelajaran dalam Jaringan (daring) atau Online}

Pembelajaran daring dipercaya dapat memutus rantai penyebaran Covid-19, namun memberikan tanggung jawab pada orang tua karena orangtua menjadi guru kepada anakanaknya. Belajar dari rumah di masa pandemi dilaksanakan dengan pembelajaran jarak jauh, memanfaatkan kemajuan teknologi digital. Di tengah pandemi Covid kemajuan teknologi digital dapat memudahkan kita, kehidupan menjadi lebih efektif dan fleksibel (Suhendro 2020). Pembelajaran daring menggunakan media HP melalui sosial media berupa Whatsapp dan Youtube. Selain orang tua diberi panduan belajar, pendidik juga mengingatkan tugas peserta didik setiap hari melalui WhatsApp. Tugas dikirim melalui aplikasi WhatsApp, karena WhatsApp merupakan aplikasi yang mudah untuk digunakan dan banyak orangtua yang menggunakannya. Tidak hanya WhatsApp, untuk pembelajaran yang menggunakan video, orang tua dapat mengaksesnya melalui Youtube. Seperti hal nya saat kegiatan senam di hari Jumat, guru membagikan link video senam ke WhatsApp grup kelas, kemudian orangtua mengakses link tersebut ke Youtube. Selanjutnya di RA Ar Rasyid juga memberikan layanan belajar melalui Videocall, kegiatan ini dilakukan dengan satu guru mengampu dua peserta didik selama 40 menit.

\section{Pembelajaran Luar Jaringan (Luring) atau Offline}

Sistem pembelajaran luring merupakan sistem pembelajaran yang dilakukan secara langsung atau tatap muka (Malyana 2020). Pembelajaran luar jaringan (luring) dengan metode kunjungan belajar ke rumah atau home visit dengan media belajar berupa modul yang sudah diberikan sekolah, bahan ajar cetak, serta alat peraga yang ada di sekitar rumah. Pembelajaran luar jaringan (home visit) tentunya tetap menerapkan protokol kesehatan untuk mencegah penularan Covid-19. Pendidik selalu menggunakan masker dan face shield ketika proses belajar mengajar berlangsung, peserta didik juga menggunakan masker dan duduk berjarak. Sebelum memasuki rumah pendidik mencuci tangan dengan sabun atau dengan handsanitizer. Hal ini dilakukan untuk meminimalisir pencegahan Covid-19 sehingga guru dapat menyampaikan pembelajaran ke peserta didik. Adanya home visit menjadi salah satu kegiatan pendukung sebagai upaya untuk mengenal peserta didik dan peserta didik mengenal gurunya serta untuk melengkapi informasi mengenai peserta didik. Pembelajaran luring lebih maksimal karena untuk anak usia PAUD dalam belajar, harus melihat contoh yang nyata dibandingkan dengan daring yang hanya melihat melalui gadget, meskipun ada praktiknya tapi hasilnya berbeda. Pembelajaran daring dengan aplikasi zoom atau google meet hanya cocok untuk anak-anak dengan tipe belajar visual, sedangkan untuk anak dengan tipe belajar kinestetik dan audio kurang maksimal. Jadi perlu adanya pembelajaran secara daring dan luring, untuk menyeimbangkan karaktersitik belajar anak (wawancara dengan bunda Tatik) Home visit ini di harapkan mampu membantu orang tua menyelesaikan masalah pembelajaran yang dihadapi siswa, seperti halnya dalam membaca dan hafalan. Adanya kegiatan home visit memudahkan pendidik untuk mengetahui karakter siswa. Karena jika hanya dengan pembelajaran daring, pendidik tidak mengetahui karakter siswa secara maksimal (wawancara dengan bunda Uul). Kegiatan homevisit ini dapat terwujud secara maksimal jika didukung dengan komunikasi yang baik antara pendidik dengan orangtua, untuk menciptakan suasana belajar yang harmonis bagi peserta didik sehinga peserta didik dapat mengembangkan potensinya.

\section{Pembahasan}

Di tengah pandemi covid-19 banyak lembaga pendidikan di Indonesia yang menerapkan pembelajaran jarak jauh (daring), hal ini dilakukan karena adanya anjuran belajar dari rumah. Pembelajaran jarak jauh (PJJ) merupakan praktik baru dalam proses pembelajaran. Dengan pembelajaran jarak jauh menjadikan orang tua kembali menjalankan perannya sebagai "guru" dirumah, orang tua harus membimbing, mengawasi, mendidik serta mengevaluasi proses belajar 
anak. Kebijakan Belajar Dari Rumah (BDR) di TK melibatkan orang tua juga tidak hanya guru dan siswa (808-4583-1-PB.pdf n.d.). Adanya PJJ ini banyak guru dan lembaga PAUD yang belum siap, sehingga mereka hanya memindahkan Rencana Pelaksanan Pembelajaran Harian (RPPH) tatap muka menjadi pembelajaran jarak jauh. Akibatnya banyak siswa yang cepat bosan melaksanakan pembelajaran jarak jauh. Pada pembelajaran tatap muka di sekolah, anak dapat berinteraksi dengan guru dan teman-teman, sehingga anak lebih semangat dan mudah mengikuti pembelajaran yang diperintahkan guru. Tidak hanya itu, dengan pembelajaran tatap muka guru dapat mengamati secara langsung tingkah laku anak, sehingga apabila anak berperilaku sedikit menyimpang, guru dapat langsung mengkoreksi dan melaporkan pada orang tua. Hal ini menjadi berbeda ketika adanya pembelajaran jarak jauh (PJJ) interaksi hanya searah, anak hanya mengikuti pembelajaran melalui gadget. Pembelajaran dengan sistem daring tentu saja masih mengalami banyak permasalahan dalam penerapannya. Seperti halnya anak tidak dapat belajar sendiri dengan menggunakan HP tanpa bantuan dari orang dewasa. Ketersediaan paket data juga menjadi hal yang perlu diperhitungkan dalam pembelajaran daring ini. Dalam penyampaian proses pembelajaran menggunakan aplikasi WA yang memerlukan paket data internet, jika orangtua tidak memiliki paket data internet maka anak tidak dapat mengikuti pembelajaran. Untuk mendukung kelancaran pembelajaran jarak jauh (daring), diperlukan strategi pembelajaran yang tepat untuk mencapai tujuan pendidikan di tengah pandemi covid-19 seperti saat ini. Strategi yang dilakukan untuk menyampaikan pembelajaran adalah dengan menerapkan metode pembelajaran daring dan luring.

Beberapa guru PAUD telah melaksanakan pembelajaran dalam satu tahun ini dengan menerapkan beberapa strategi pembelajaran. Strategi pembelajaran daring dengan melakukan belajar melalui WhatsApp grup, segala informasi terkait pembelajaran disampaikan guru melalui WhatsApp grup. Pembelajaran dengan metode daring mengalami banyak kendala, seperti halnya ketika proses kegiatan belajar yang telah dirancang, kadang tidak sesuai dengan rencana. Kadang guru menerima keluhan dari orang tua tentang bagaimana cara mengerjakan tugas tersebut, bagaimana cara mengajarkan anak dalam menghafalkan surat-surat pendek. Mengatasi permasalahan ini, guru memberikan video pembelajaran yang sesuai dengan tugas tersebut dan dikirim ke WhatsApp grup kelas. Sama halnya dalam menghafalkan surat-surat pendek, guru juga memberikan video animasi dengan hafalan satu hari satu ayat (wawancara dengan bunda Diah). Hal ini bertujuan untuk memudahkan orang tua dalam mendampingi anak belajar di rumah. Rata-rata video dikirim melalui aplikasi WhatsApp, karena WhatsApp merupakan aplikasi yang mudah untuk digunakan dan banyak orang tua yang menggunakannya. Tidak hanya menyampaikan pembelajaran lewat Whatsapp guru juga memberikan panduan belajar pada orang tua setiap dua minggu sekali. Pemberian panduan belajar ini, selain memberikan peralatan belajar, juga memberikan kesempatan pada orangtua untuk menyampaikan perkembangan anak selama belajar daring. Adanya pertemuan dengan orang tua setiap dua minggu sekali, juga memberikan kesempatan pada guru untuk mengenal karakter anak lebih dalam. Tentunya dalam pertemuan ini RA Ar Rasyid menerapkan protokol kesehatan, dengan jadwal pengambilan antara kelas satu dengan kelas yang lain berbeda. Hal ini bertujuan agar tidak menimbulkan kerumunan dan orang tua yang akan masuk ke sekolah harus cuci tangan terlebih dahulu serta di cek suhunya. Dalam menerapkan strategi pembelajaran ditengah pandemi ini, tim kurikulum selalu mengevaluasi strategi yang telah diterapkan agar anak tidak cepat bosan.

Strategi daring selain belajar melalui WhatsApp grup kelas, juga dengan menggunakan Video Call. Belajar melalui Video Call dilakukan dalam seminggu 3 kali mulai pukul 08.00 WIB-17.00 WIB, guru membuka layanan belajar melalui video call sampai sore, karena banyak orang tua yang bekerja sehingga bisa mendampingi belajar ketika sore. Teknis belajar melalui Video Call ini satu guru mengampu 2 anak dengan durasi waktu belajar 30 menit. Menurut pandangan orang tua anak, belajar melalui video call memberikan nilai positif bagi anak, anakanak menjadi lebih semangat belajar. Anak-anak senang karena dapat berinteraksi dengan guru, teman, serta anak jadi kenal dengan teman-teman sekelasnya. Namun, belajar melalui video call juga memiliki kekurangan diantaranya, terkendala dalam sinyal. Ketika pembelajaran sedang 
berlangsung tiba-tiba koneksi internetnya buruk, sehingga guru harus mengulang lagi dari awal, sinyal internet yang kurang mendukung membuat pembelajaran berjalan tidak maksimal. Waktu belajar yang terlalu singkat hanya 30 menit, dalam menyampaikan pembelajaran guru terkesan buru-buru terutama saat hafalan surat-surat pendek (wawancara dengan ibu Lina). Pembelajaran daring dapat meningkatkan motivasi belajar anak apabila, adanya dukungan dari orang tua dan pendidik, sehingga tercipta suasana belajar yang menyenangkan. Di tengah pandemi ini peran utama pendidik adalah menciptakan suasana belajar yang menyenangkan sesuai dengan prinsip belajar anak usia dini, yaitu bermain sambil belajar, belajar sambil bermain. Hal ini juga di ungkapkan oleh (Amalina 2020) pembelajaran pada anak usia dini di tengah pandemi covid-19 diharapkan mampu menciptakan suasana belajar yang menyenangkan, sehingga anak tidak mudah bosan dan anak merasa tidak terbebani dengan tugas yang diberikan oleh guru. Oleh karena itu, untuk memperkuat pembelajaran jarak jauh (daring) diperlukan pendekatan pembelajaran yang ramah anak, dan mudah dikerjakan saat dirumah bersama orangtua.

Implementasi strategi home visit ini diawali dengan perencanaan yang matang, antara kepala sekolah, guru, tim kurikulum. Strategi home visit ini, terlebih dahulu disampaikan orangtua, guna untuk mendapatkan persetujuan dari orang tua. Hal ini menjadi bukti bahwa keterlibatan orang tua tidak bisa dipisahkan dari dunia pendidikan anak usia dini terlebih dalam situasi pandemi, karena dalam belajar anak usia dini masih memerlukan dampingan orang dewasa disekitarnya (Zephanya, Latiana, and Formen 2020). Setelah mendapatkan persetujuan orang tua, guru membuat jadwal kunjungan setiap minggunya. Kegiatan home visit yang dilakukan pendidik merupakan sarana untuk memberikan informasi pada orang tua, terkait halhal yang perlu dilakukan orang tua dalam mendukung perkembangan potensi anak, dan bakat secara menyeluruh selama pandemi ini. (Nirmala and Annuar 2020) Kegiatan home visit merupakan layanan pendukung yang mengedepankan keterpaduan berbagai pelayanan pada siswa dan orang tua. Home visit dilaksanakan agar guru tetap dapat memberikan layanan dan menstimulasi anak selama pandemi ini. Komunikasi antara guru dan orang tua dalam pelaksanaan home visit ini sangat dibutuhkan karena orang tua dapat melanjutkan proses belajar selama anak dirumah. Kerja sama antara guru, orang tua serta masyarakat sangat penting dalam mewujudkan tujuan pendidikan dan pengasuhan anak (Getswicki, 2015). Pelaksanaan home visit ini dilakukan satu minggu 3 kali dengan waktu belajar selama 90 menit. Guru membagi satu kelas menjadi 4 kelompok, setiap kelompok terdiri dari 5 anak dengan 2 guru. Tidak hanya belajar membaca dan hafalan surat-surat pendek, dalam home visit ini anak juga diajak untuk sholat dhuha, tujuannya untuk mengingatkan kembali bacaan-bacaan dalam sholat. Selama kegiatan home visit guru dan siswa selalu menerapkan protokol kesehatan, guna untuk mencegah penularan covid-19. Adanya kegiatan homevisit ini banyak orangtua yang memberikan respon positif, karena anak-anak menjadi lebih semangat belajar. Hal ini terlihat ketika mereka menyambut guru, semangat dalam mengikuti pembelajaran, tidak ada yang menangis dan anak-anak dapat menyelesaikan tugasnya secara mandiri (wawancara dengan bu Tri Haryanti). Bahkan dengan adanya kegiatan home visit ini, anak yang biasanya bangun siang menjadi bangun lebih pagi, anak yang biasanya tidur terlalu malam karena keesokan harinya akan home visit, tidur lebih awal. Hal lain juga di ungkapkan oleh orang tua home visit membantu anak menjadi mudah menghafalkan surat-surat pendek dan membangkit kan semangat anak didik. Program home visit memberikan manfaat untuk guru, siswa dan orang tua. Adanya home visit mendorong orang tua untuk ikut memotivasi anak agar semangat belajar. Sehari sebelum home visit, guru menyampaikan alat dan bahan yang perlu di siapkan saat home visit melalui WhatsApp grup kelas. Dengan pemberitahuan tersebut mendorong wali murid untuk memperhatikan kebutuhan anak. Namun meskipun menurut beberapa walimurid homevisit memberikan dampak yang positif, ada beberapa walimurid yang tidak mengizinkan anaknya untuk mengikuti homevisit tersebut, dengan alasan kesehatan. Kegiatan home visit ini menjadi kegitan yang tidak wajib, jika orang tua tidak mengizinkan anaknya untuk home visit, diganti dengan belajar melalui video call dengan durasi 40 menit. 


\section{Simpulan dan Saran}

Berdasarkan analisis di atas penerapan strategi pembelajaran yang dilakukan oleh guru saat pandemi ini adalah dengan metode daring dan luring. Pembelajaran secara daring dilakukan dengan cara, mengirim tugas melalui sosial media WhatsApp, melakukan videocall dan youtube. Sedangkan pembelajaran dengan metode luring, dilakukan dengan cara membagi anak menjadi 4 kelompok. Setiap kelompok terdiri dari 5 orang anak dengan 2 guru, setiap dua minggu guru menyampaikan jadwal home visit ke WhatsApp grup kelas. Adanya program home visit diharapkan mampu menumbuhkan semangat anak dalam belajar, meskipun belajar dari rumah. Tentunya dalam belajar secara daring banyak kekurangan, dengan diberikannya program home visit diharapkan mampu menutup kekurangan daring tersebut. Ketika pembelajaran daring sebaiknya guru dalam menyampaikan pembelajaran menggunakan media pembelajaran yang menarik, sehingga anak lebih semangat mengikuti pembelajaran. Di harapkan strategi ini bisa menjadi solusi bagi guru PAUD yang telah melaksanakan pembelajaran di tengah pandemi covid-19 ini, sehingga proses belajar di tengah pandemi dapat berjalan sesuai dengan tujuan pendidikan.

\section{Daftar Rujukan}

Amalina, Amalina. 2020. "Pembelajaran Matematika Anak Usia Dini Di Masa Pandemi COVID-19 Tahun 2020.” Jurnal Obsesi : Jurnal Pendidikan Anak Usia Dini 5(1): 538.

"Astuti, Yuli\&Harun.2021. "Tantangan Guru dan Orang Tua dalam Kegiatan Belajar Dari Rumah Anak Usia Dini pada Masa Pandemi Covid-19." Jurnal Obsesi : Jurnal Pendidikan Anak Usia Dini 5(2):1441.

Hewi, La, and Linda Asnawati. 2020. "Strategi Pendidik Anak Usia Dini Era Covid-19 Dalam Menumbuhkan Kemampuan Berfikir Logis." Jurnal Obsesi : Jurnal Pendidikan Anak Usia Dini 5(1): 158.

Indahri, Yulia. 2020. "Permasalahan Pembelajaran Jarak Jauh Di Era Pandemi." Pusat Penelitian Badan Keahlian DPR $R \quad$ 19: $13-18$. https://berkas.dpr.go.id/puslit/files/info_singkat/Info Singkat-XII-12-II-P3DI-Juni-2020201.pdf.

Kemendikbud. 2014. "Peraturan Menteri Pendidikan Dan Kebudayaan Republik Indonesia Nomor 119 Tahun 2014 Tentang Penyelenggaraan Pendidikan Jarak Jauh Jenjang Pendidikan Dasar Dan Menengah." Peraturan Menteri Pendidikan Dan Kebudayaan Republik Indonesia Nomor 119 Tahun 2014 Tentang Penyelenggaraan Pendidikan Jarak Jauh Jenjang Pendidikan Dasar Dan Menengah (1650): 1-12. http://luk.tsipil.ugm.ac.id/atur/bsnp/Permendikbud119-2014PJJ-Dikdasmen.pdf.

Malyana, Andasia. 2020. "Pelaksanaan Pembelajaran Daring Dan Luring Dengan Metode Bimbingan Berkelanjutan Pada Guru Sekolah Dasar Di Teluk Betung Utara Bandar Lampung." Jurnal Ilmiah Pendidikan Dasar Indonesia 2(1): 67-76.

Nirmala, Besse, and Haerul Annuar. 2020. "Home Visit: Strategi PAUD Dari Rumah Bagi Guru Di Daerah 3T Pada Masa Pandemi Covid-19." Jurnal Obsesi : Jurnal Pendidikan Anak Usia Dini 5(2): 1052-62.

Pg-paud, Program Studi, Fakultas Keguruan, and Universitas Islam Nusantara. 2020. "Tumbuh Kembang: Kajian Teori Dan Pembelajaran PAUD Jurnal PG-PAUD FKIP Universitas Sriwijaya Bermain Di Rumah Untuk Anak Usia Dini Dimasa Pandemi COVID-19." (November).

Suhendro, Eko. 2020. "Strategi Pembelajaran Pendidikan Anak Usia Dini Di Masa Pandemi Covid-19." Golden Age: Jurnal Ilmiah Tumbuh Kembang Anak Usia Dini 5(3): 133-40.

Zamzami, Elviawaty Muisa. 2020. "Aplikasi Edutainment Pendukung Pembelajaran Jarak Jauh TK Merujuk Standar Nasional PAUD.” Jurnal Obsesi : Jurnal Pendidikan Anak Usia Dini 5(2): 985-95.

Zephanya, Virgilia, Lita Latiana, and Ali Formen. 2020. "Penguatan Pembelajaran Jarak Jauh Anak Usia Dini Melalui Pendekatan STEAM Dan Pemberdayaan Keluarga." 